Економічні науки: збірник наукових праць Луцького національного технічного університету. Серія "Регіональна економіка". Випуск 18 (71). Редкол.: відп. ред. д.е.н., професор Л.Л. Ковальська. Луцьк: ІВВ Луцького НТУ, 2021. 278 с.

УДК 338.439 .54

Талавиря М.П., д.е.н., професор

директор науково-дослідного інституту

Костюк Т.О., к.е.н., доцент кафедри економіки

Національний університет біоресурсів і природокористування України

\title{
ПРОДОВОЛЬЧА БЕЗПЕКА В УМОВАХ СУЧАСНИХ ЕКОНОМІЧНИХ ВИКЛИКІВ
}

Актуальність досліджуваної проблематики додатково визначається потребами одночасної екологізації й соціалізації сільськогосподарського виробництва, з метою збереження навколишнього природного середовища за рахунок раціонального природо-користування та мінімізації безробіття на селі.

У статті охарактеризовано сучасний стан продовольчої безпеки. Сформульовано основні напрямки ii розвитку. Детально проаналізовано сучасний стан продовольчої безпеки в умовах нових викликів. Обгрунтовано рекомендації та організаційно-методичні підходи до розвитку продовольчої безпеки.

Ключові слова: продовольча безпека; економічна безпека; соціальна безпека; індикатори; інтегральний індекс; екологічна безпека;вектори.

Talavyrya M, Kostyuk T.

\section{FOOD SECURITY IN THE CONDITIONS OF MODERN ECONOMIC CHALLENGES}

The relevance of the studied issues is additionally determined by the needs of simultaneous greening and socialization of agricultural production, in order to preserve the environment through the rational use of nature and minimize unemployment in rural areas.

The article describes the current state of food security. The main directions of its development are formulated. The current state of food security in the face of new challenges is analyzed in detail. Recommendations and organizational and methodological approaches to the development of food security are substantiated.

Key words: food security; economic security; social security; indicators; integral index; environmental safety, vectors

Талавиря Н.П., Костюк Т.О.

\section{ПРОДОВОЛЬСТВЕННАЯ БЕЗОПАСНОСТЬ В УСЛОВИЯХ СОВРЕМЕННЫХ ЭКОНОМИЧЕСКИХ ВЫЗОВОВ}

\footnotetext{
Актуальность исследуемой проблематики дополнительно определяется потребностями одновременной экологизации и социализации
} 
Економічні науки: збірник наукових праць Луцького національного технічного університету. Серія "Регіональна економіка". Випуск 18 (71). Редкол.: відп. ред. д.е.н., професор Л.Л. Ковальська. Луцьк: ІВВ Луцького НТУ, 2021. 278 с.

сельскохозяйственного производства, с целью сохранения окружающей среды за счет рационального природопользования и минимизации безработицы на селе.

В статье охарактеризовано современное состояние продовольственной безопасности. Сформулированы основные направления ее развития. Детально проанализировано состояние продовольственной безопасности в условиях новых вызовов. Обоснованы рекомендации и организационно методические подходы к развитию продовольственной безопасности.

Ключевые слова: продовольственная безопасность; экономическая безопасность; социальная безопасность; индикаторы; интегральный индекс; экологическая безопасность; векторы.

Мета статті - зробити наукову оцінку сучасного стану продовольчої безпеки в умовах нових викликів щодо шляхів розвитку економічної безпеки сільського господарства України в умовах сучасних викликів.

Методика дослідження. Використовувалися такі методи: монографічний (для всебічного й глибокого вивчення окремих явищ, процесів та виявлення причинно-наслідкових зв'язків їх розвитку), системний (полягає у дослідженні певних об'єктів як складних систем), економіко-математичний (дав змогу встановити кількісний вплив окремих факторів на досліджуваний результат), статистичний (під час роботи зі статистичною інформацією та аналітичних розрахунків).

Результати дослідження. Для ідентифікації рівня соціальної та екологічної складових економічної безпеки у галузі сільського господарства розроблено перелік індикаторів розвитку для різних сфер діяльності. Наведений перелік не є сталим та може бути змінений залежно від глибини та цілей дослідження.

В процесі дослідження запропоновано новий підхід визначення індикатора оцінки векторів порогових значень (нижній порогів барєр, оптимальний, верхній допустимий, верхній поріг) за методом “t-критерію”. Ми встановили та визначили головні загрози безпечного існування економічної системи - соціально-екологічної безпеки сільського господарства України. Економічні виклики базуються на майже 
Економічні науки: збірник наукових праць Луцького національного технічного університету. Серія "Регіональна економіка". Випуск 18 (71). Редкол.: відп. ред. д.е.н., професор Л.Л. Ковальська. Луиьк: ІВВ Луцьького НТУ, 2021. 278 с.

78 \% показників, які становлять відповідний рівень безпечного існування.

Наукова новизна полягає в обгрунтуванні теоретичних, методичних i практичних рекомендацій щодо формування пріоритетів зміцнення економічної безпеки сільського господарства України.

Постановка проблеми. У сучасних умовах від рівня економічної безпеки сільського господарства залежить розвиток національної економіки України, оскільки сільське господарство та суміжні галузі формують значну частку експортного ринку, слугують надійним джерелом валютних надходжень до державного бюджету. Водночас загальний рівень економічної безпеки сільського господарства характеризується значною економічною розбалансованістю i соціально-екологічними диспропорціями, неготовністю реагувати на внутрішні та зовнішні виклики, які ставлять під загрозу подальший розвиток національної економіки.

Аналіз останніх досліджень і публікацій. Детально проаналізовано сучасний стан продовольчої безпеки в умовах нових викликів та зроблено оцінку показників економічної безпеки у наукових працях вітчизняних учених, серед яких В. Заліско, 3. Варналій, А. Сухоруков, В. Геєць, Я. Жаліло, Ю. Харазішвілі, Б. Данилишин, В. Мунтіян, А. Сундук, С. Кваша, та інші дослідники. Іноземні вчені внесли вагомий вклад у вивчення даного питання: Л. Абалкін, В. Богомолов, М. Фрідмен, І. Кроз, В. Кузнєцов, Ф. Роджерс, В. Сенчагов.

Виклад основних результатів дослідження. У більшості наукових досліджень, зокрема й в офіційній методиці оцінки економічної безпеки відсутня соціально-екологічна складова, що суттєво обмежує їх доказову базу. Спираючись на принципи сталого розвитку, на нашу думку, соціально-екологічна складова являє собою найважливішу складову не лише економічної безпеки сільського господарства, а й усієї національної економіки. Додатково це підкреслюється 13 статтею Конституції України, де серед іншого зазначено, що Україна є соціальною державою [1]. Підвищення рівня 
Економічні науки: збірник наукових праць Луцького національного технічного університету. Серія "Регіональна економіка". Випуск 18 (71). Редкол.: відп. ред. д.е.н., професор Л.Л. Ковальська. Луиьк: ІВВ Луиького НТУ, 2021. 278 с.

економічної безпеки на всіх рівнях національної економіки неможливе без соціальної та екологічної захищеності населення у містах та селах нашої країни. На сьогодні існує недостатньо сформоване наукове підгрунтя для кількісного визначення цих стратегічних індикаторів.

Значна частина вчених не пов'язували свої дослідження 3 екологічними проблемами розвитку сільського господарства. Разом із тим, незважаючи на досить велику кількість публікацій у сфері сталого розвитку та економічної безпеки (О. Новікова, О. Амоша, В. Антонюк [8], Ю. Харазішвілі, В. Дронь, В. Ляшенко [9], В. Залізко [10, 11] та інші), дослідження соціальної та екологічної складових економічної безпеки сільського господарства залишилися недостатньо висвітленими у науковій літературі.

Соціальна, економічна та екологічна безпека досліджувалися у провідних наукових центрах України та світу.

Такий підхід дозволяє на теоретичному рівні оцінити становище соціальної інфраструктури сільських територій, враховуючи їх деградацію, низькі доходи сільського населення, демографічні та екологічні проблеми. Це перетворює подібне дослідження не лише на актуальне, а й нагальне, оскільки воно за сучасних умов значною мірою впливає на рівень економічної захищеності сільського господарства.

Нижче детальніше будуть розглянуті соціальні та екологічні складові та їх індикатори економічної безпеки сільського господарства. Кожна значення складових має відповідний набір індикаторів, які можна віднести до стимуляторів або до де стимуляторів.

Для однозначного оцінювання соціальної складової економічної безпеки сільського господарства аналітично визначимо інтегральний індекс, який забезпечуватиме методологічну єдність усіх показників. Дослідження методичних підходів до інтегрального оцінювання стану розвитку або безпеки виявило низку недоліків, які призводять до викривлених оцінок, тому застосовуються сучасні досягнення інтегрального оцінювання рівня безпеки [15]. 
Економічні науки: збірник наукових праць Луцького національного технічного університету. Серія "Регіональна економіка". Випуск 18 (71). Редкол.: відп. ред. д.е.н., професор Л.Л. Ковальська. Луиьк: ІВВ Луиького НТУ, 2021. 278 с.

Отже, використовуючи для розрахунку інтегрального індексу оцінювання соціальної складової економічної безпеки сільського господарства сучасні підходи [11, 16, 17, 15], отримаємо динаміку інтегрального індексу соціальної безпеки.

Різнобічний підхід інтегрального оцінювання рівня безпеки, що використовується, передбачає одночасне нормування як індикаторів. Новий підхід дав оцінку порівнювати в одному масштабі динаміку інтегрального індексу та інтегральних порогових значень, тобто ідентифікувати стан виробничої безпеки.

За аналізований період рівень соціальної безпеки сільського господарства тільки у 2006-2012 рр. знаходився між нижнім пороговим та нижнім оптимальним значеннями, тобто у передкризовій зоні, а з 2013 по 2016 рр. - нижче нижнього порогового значення з негативною динамікою. Наведене вказує на значну загрозу соціальній безпеці та свідчить про неефективне керування соціальною безпекою галузі. $370 \%$ індикаторів соціальної безпеки $40 \%$ знаходиться нижче нижнього порога, 35\% - на межі нижнього порога і тільки один - в оптимальній зоні.

Отже, головною причиною низького інтегрального рівня соціальної безпеки сільського господарства України $\epsilon$ перебування низки індикаторів нижче або на межі нижнього порога.

Екологічна безпека сільського господарства. Враховуючи територіальні особливості розміщення, спочатку дослідимо проблем зміцнення екологічної безпеки селітебних та сільськогосподарських земель, які безпосередньо впливають на економічну безпеку сільського господарства, сільських територій та країни загалом.

У XXI ст. економічні та екологічні проблеми у результаті глобалізаційних процесів створюють загрозу голоду та скорочення життя на всій планеті. Негативний антропогенний влив на якість грунтів, висока інтенсивність господарювання, масове вирубування лісів, чорнобильська катастрофа, утворення міст та сіл «привидів» (спустошених у результаті спаду 
Економічні науки: збірник наукових праць Луцького національного технічного університету. Серія "Регіональна економіка". Випуск 18 (71). Редкол.: відп. ред. д.е.н., професор Л.Л. Ковальська. Луиьк: ІВВ Луиького НТУ, 2021. 278 с.

економічної діяльності або техногенних катастроф) призводять до серйозних еколого-економічних деформацій, які ослаблюють економічну безпеку України та сусідніх країн, що підтверджує актуальність та важливість досліджуваної тематики.

За часів колишнього Радянського Союзу в економіках його республік працювало олімпійське правило «вище, швидше, сильніше», яке в основному втілювалось у зростанні валового внутрішнього продукту. Вважалося, чим більше буде розорано та посіяно, і в результаті зібрано урожаю, тим швидше настане комунізм i покращиться добробут населення. Проблеми екології, що стосуються якості земель, історичної їх цінності, не були тоді на першому плані, i навіть сьогодні вони розглядаються виключно у теоретичній площині. Так само, як за часів фашистської окупації вивозили ешелонами український родючий чорнозем, сьогодні, щоправда в інший спосіб, знищується віковий капітал України - родюча земля. Останнім часом спостерігається «варварське» ставлення до земель сільськогосподарського призначення та селітебних сільських територій, яке не підлягає логічному поясненню.

Нагадаємо, що поняття «селітебна територія» застосовується до тих земель, на яких розміщуються житлові квартали, ділянки культурно-побутових та суспільних будівель, зелені насадження суспільного призначення, вулиці, площі тощо. Дослідження у цій сфері частіше проводяться для міських територій, оскільки там антропогенний вплив більш значний внаслідок високої концентрації населення.

Для вирішення екологічних проблем останнім часом відбулася активізація кредитних операцій серед сільських жителів та підприємців, що деякими вченими вважається позитивною ознакою і можливим шляхом до економічного зростання та розширення середнього класу на селі (йдеться про так звані «теплі кредити»). Проте більшість кредитних ставок коливаються від 2 до $4 \%$ на місяць і, враховуючи страхові внески та інші виплати, за два роки користування такими кредитами переплата становитиме майже $100 \%$ суми кредиту. Невигідність вітчизняного кредитування підтверджується 
Економічні науки: збірник наукових праць Луцького національного технічного університету. Серія "Регіональна економіка". Випуск 18 (71). Редкол.: відп. ред. д.е.н., професор Л.Л. Ковальська. Луиьк: ІВВ Луиького НТУ, 2021. 278 с.

даними Державного управління статистики, згідно 3 яким учасниками фінансово-кредитних відносин $є$ лише $13,6 \%$ провідних сільськогосподарських приватних підприємців $(21,8 \%$ респондентів вважають, що не зможуть повернути отриманий кредит [11). Погоджуємося з думкою В. Залізка щодо недоцільності використання однакових методів вирішення соціальних проблем для всіх населених пунктів України, оскільки це все одно що розробляти їх для кожного окремо. Найоптимальнішим способом зміцнення економічної безпеки сільського господарства видається виокремлення характерних соціо-еколого-економічних загроз, які пропонується оцінювати за методологією інтегрального оцінювання 3 позицій економічної безпеки [10].

За результатами розрахунків рівень екологічної безпеки сільського господарства за 12 років знаходиться практично у стабільному передкризовому стані - на рівні нижнього порогового значення. Це вказує на повну бездіяльність керівництва галузі в екологічній сфері сільського господарства, що підтверджує динаміка індикаторів екологічної безпеки. 3 5ти індикаторів екологічної безпеки 3 знаходяться у критичній зоні - нижче нижнього порогового значення: рівень удобреної площі мінеральними добривами, \% (S); рівень розораності території, \% (D); рівень розораності сільськогосподарських земель, \% (D).

Виконуючи наступний етап інтегральної згортки порогових значень (табл. 1) та індикаторів, отримаємо динаміку інтегрального індексу соціально-екологічної безпеки сільського господарства.

Відомо, що одну 3 найголовніших складових інфраструктури будь-якої системи становить іiі енергетична складова. Наявність електропостачання відкрила широкі можливості використання сучасних науково-технічних винаходів, що спростило виконання багатьох видів сільськогосподарських робіт та покращило побутові умови проживання сільського населення. Проте на сьогодні електрична 
Економічні науки: збірник наукових праць Луцького національного технічного університету. Серія "Регіональна економіка". Випуск 18 (71). Редкол.: відп. ред. д.е.н., професор Л.Л. Ковальська. Луиьк: ІВВ Луцьького НТУ, 2021. 278 с.

енергія на сільських територіях використовується не повною мірою.

Таблиця 1

Вектори порогових значень складових соціально-екологічної безпеки сільського господарства України

\begin{tabular}{|l|c|c|c|c|}
\hline \multicolumn{1}{|c|}{ Вид безпеки } & $\begin{array}{c}\text { Нижнє } \\
\text { порогове }\end{array}$ & $\begin{array}{c}\text { Нижнє } \\
\text { оптимальне }\end{array}$ & $\begin{array}{c}\text { Верхнє } \\
\text { оптимальне }\end{array}$ & $\begin{array}{c}\text { Верхнє } \\
\text { порогове }\end{array}$ \\
\hline Соціальна & 0,3533 & 0,5563 & 0,7196 & 0,8852 \\
\hline Екологічна & 0,2028 & 0,4325 & 0,6469 & 0,9211 \\
\hline $\begin{array}{l}\text { Соціально- } \\
\text { екологічна } \\
\text { безпека } \\
\begin{array}{l}\text { сільського } \\
\text { господарства }\end{array}\end{array}$ & 0,2726 & 0,4946 & 0,6847 & 0,9018 \\
\hline
\end{tabular}

Так, на опалення споруд та підігрівання води витрачається енергія згорання природного газу чи твердого палива (дрова, вугілля, брикет і т.д.). Це при тому, що показники коефіцієнта корисної дії у них гірші, а закупівельні ціни - високі. Більше того, держава невиправдано витрачає бюджетні кошти на газифікацію сіл, тоді як за останні роки виникало ряд політичногазових та військових проблем, зростали ціни на природний газ i нафтопродукти. Звідси зрозуміло, що варто інтенсивніше використовувати електроенергію.

Як відомо, на території України (до останнього часу) електроенергії вироблялося 3 надлишком. У такому разі доцільно шукати інноваційні способи збільшення інтенсивності та ефективності використання електричної енергії на сільських територіях України. Зокрема, видається доречним введення додаткових пільг на електроенергію у сільській місцевості. Як наслідок, для приватного бізнесу з'явиться стимул активніше відкривати в межах сільських територій несільськогосподарські підприємства, які потребують значних витрат електроенергії. У свою чергу це позитивно вплине на зниження сільського безробіття та надасть поштовх економіці сільського господарства. 
Економічні науки: збірник наукових праць Луцького національного технічного університету. Серія "Регіональна економіка". Випуск 18 (71). Редкол.: відп. ред. д.е.н., професор Л.Л. Ковальська. Луиьк: ІВВ Луцьького НТУ, 2021. 278 с.

За поширення на більшості сільських територій України аграрного виробництва, нині у зв'язку зі створенням сучасних автоматизованих комплексів із використанням комп'ютерних технологій кількість людей, задіяних у сільськогосподарському виробництві, зменшилася у рази. Так, приватному підприємцю за наявності сучасної техніки достатньо вісьмох працівників для обслуговування понад 5000 га орних земель. Тобто, скупивши (чи взявши в оренду) землі сільських територій одного села роботу отримає до $1 \%$ населення. Однією 3 відповідей на питання, що робити решті $99 \%$, можливо, є модернізація сільської системи складських приміщень, ангарів та заготівельних контор, а також створення на таких сільських територіях пунктів з переробки вирощеної продукції, на яких буде розміщено сушильне, охолоджувальне, сортувальне обладнання тощо.

Отже, на перспективу подальших досліджень існує необхідність врахування індикаторів енергетичної безпеки сільського господарства в екологічній складовій. Для соціальної складової потрібне залучення індикаторів рівня життя, тіньової зайнятості, тіньової заробітної плати та ін.

\section{Список бібліографічного опису}

1.Про внесення змін до Закону України "Про фермерське господарство" щодо стимулювання створення та діяльності сімейних фермерських господарств : закон України від 31.03.2016 № 1067-19 / Відомості Верховної Ради (ВВР), 2016, № 21, ст.406

2.Про внесення змін до Закону України "Про фермерське господарство" щодо стимулювання створення та діяльності сімейних фермерських господарств : закон України від 31.03.2016 № 1067-19 / Відомості Верховної Ради (ВВР), 2016, № 21, ст.406

3.Про внесення змін до Закону України "Про фермерське господарство" щодо стимулювання створення та діяльності сімейних фермерських господарств : закон України від 31.03.2016 № 1067-19 / Відомості Верховної Ради (ВВР), 2016, № 21, ст.406

4.Про внесення змін до Закону України "Про фермерське господарство" щодо стимулювання створення та діяльності сімейних фермерських господарств : закон України від 31.03.2016 № 1067-19 / Відомості Верховної Ради (ВВР), 2016, № 21, ст.406

5.Про внесення змін до Закону України "Про фермерське господарство" щодо стимулювання створення та діяльності сімейних 
Економічні науки: збірник наукових праць Луцького національного технічного університету. Серія "Регіональна економіка". Випуск 18 (71). Редкол.: відп. ред. д.е.н., професор Л.Л. Ковальська. Луцьк: ІВВ Луцького НТУ, 2021. 278 с.

фермерських господарств : закон України від 31.03.2016 № 1067-19 / Відомості Верховної Ради (ВВР), 2016, № 21, ст.406

6.Про внесення змін до Закону України "Про фермерське господарство" щодо стимулювання створення та діяльності сімейних фермерських господарств : закон України від 31.03.2016 № 1067-19 / Відомості Верховної Ради (ВВР), 2016, № 21, ст.406

7.Про внесення змін до Закону України "Про фермерське господарство" щодо стимулювання створення та діяльності сімейних фермерських господарств : закон України від 31.03.2016 № 1067-19 / Відомості Верховної Ради (ВВР), 2016, № 21, ст.406

8.Про внесення змін до Закону України "Про фермерське господарство" щодо стимулювання створення та діяльності сімейних фермерських господарств : закон України від 31.03.2016 № 1067-19 / Відомості Верховної Ради (ВВР), 2016, № 21, ст.406

9.Про внесення змін до Закону України "Про фермерське господарство" щодо стимулювання створення та діяльності сімейних фермерських господарств : закон України від 31.03.2016 № 1067-19 / Відомості Верховної Ради (ВВР), 2016, № 21, ст.406

10. Залізко В. Д. Сільські території України: стратегічні пріоритети розвитку в контексті зміцнення економічної безпеки : [монографія] / В. Д. Залізко ; Національний університет ДПС України. - Ірпінь : Видавництво НУДПСУ, 2014. - 502 с.

11. Залізко В.Д. Сільські території України: стратегічні пріоритети розвитку в контексті зміцнення економічної безпеки : [монографія] / В. Д. Залізко ; Національний університет ДПС України. - Ірпінь : Видавництво НУДПСУ, 2014. - 502 с.

12. Про внесення змін до Закону України "Про фермерське господарство" щодо стимулювання створення та діяльності сімейних фермерських господарств : закон України від 31.03.2016 № 1067-19 / Відомості Верховної Ради (ВВР), 2016, № 21, ст.406

13. Про внесення змін до Закону України "Про фермерське господарство" щодо стимулювання створення та діяльності сімейних фермерських господарств : закон України від 31.03.2016 № 1067-19 / Відомості Верховної Ради (ВВР), 2016, № 21, ст.406

14. Про внесення змін до Закону України "Про фермерське господарство" щодо стимулювання створення та діяльності сімейних фермерських господарств : закон України від 31.03.2016 № 1067-19 / Відомості Верховної Ради (ВВР), 2016, № 21, ст.406

15. Про внесення змін до Закону України "Про фермерське господарство" щодо стимулювання створення та діяльності сімейних фермерських господарств : закон України від 31.03.2016 № 1067-19 / Відомості Верховної Ради (ВВР), 2016, № 21, ст.406

16. Качинський А.Б. Засади системного аналізу безпеки складних систем. - К. : ДП “НВЦ “Евроатлантик інформ”, 2006. - 336 с. 
Економічні науки: збірник наукових праць Луцького національного технічного університету. Серія "Регіональна економіка". Випуск 18 (71). Редкол.: відп. ред. д.е.н., професор Л.Л. Ковальська. Луиьк: ІВВ Луиького НТУ, 2021. 278 с.

17. Блинов Н., Кокарев М., Крашенинников В. Об обеспечении экономической безопасности России / Н. Блинов, М. Кокарев, В. Крашенинников // Экономист. - 1996. - № 4. - С. 47-51.

18. Про внесення змін до Закону України "Про фермерське господарство" щодо стимулювання створення та діяльності сімейних фермерських господарств : закон України від 31.03.2016 № 1067-19 / Відомості Верховної Ради (ВВР), 2016, № 21, ст.406

19. Talavyria M., Nikolenko L., Kolesnyk T., Samborska O. Ensuring the sustainable development of the Ukrainian agrarian sector in conditions of globalization. Problems and Perspectives in management. 2018. № 3. P. 245-258.

\section{References}

1. On Amendments to the Law of Ukraine "On Farming" to stimulate the establishment and operation of family farms: the law of Ukraine of 31.03.2016 № 1067-19 / Bulletin of the Verkhovna Rada (VVR), 2016, № 21, p.406

2. On Amendments to the Law of Ukraine "On Farming" to stimulate the establishment and operation of family farms: the law of Ukraine of 31.03.2016 № 1067-19 / Bulletin of the Verkhovna Rada (VVR), 2016, № 21, p.406

3. On Amendments to the Law of Ukraine "On Farming" to stimulate the establishment and operation of family farms: the law of Ukraine of 31.03.2016 № 1067-19 / Bulletin of the Verkhovna Rada (VVR), 2016, № 21, p.406

4. On Amendments to the Law of Ukraine "On Farming" to stimulate the establishment and operation of family farms: the law of Ukraine of 31.03.2016 № 1067-19 / Bulletin of the Verkhovna Rada (VVR), 2016, № 21, p.406

5. On Amendments to the Law of Ukraine "On Farming" to stimulate the establishment and operation of family farms: the law of Ukraine of 31.03.2016 № 1067-19 / Bulletin of the Verkhovna Rada (VVR), 2016, № 21, p.406

6. On Amendments to the Law of Ukraine "On Farming" to stimulate the establishment and operation of family farms: the law of Ukraine of 31.03.2016 № 1067-19 / Bulletin of the Verkhovna Rada (VVR), 2016, № 21, p.406

7. On Amendments to the Law of Ukraine "On Farming" to stimulate the establishment and operation of family farms: the law of Ukraine of 31.03.2016 № 1067-19 / Bulletin of the Verkhovna Rada (VVR), 2016, № 21, p.406

8. On Amendments to the Law of Ukraine "On Farming" to stimulate the establishment and operation of family farms: the law of Ukraine of 31.03.2016 № 1067-19 / Bulletin of the Verkhovna Rada (VVR), 2016, № 21, p.406

9. On Amendments to the Law of Ukraine "On Farming" to stimulate the establishment and operation of family farms: the law of Ukraine of 31.03.2016 № 1067-19 / Bulletin of the Verkhovna Rada (VVR), 2016, № 21, p.406

10. Zalizko VD Rural territories of Ukraine: strategic priorities of development in the context of strengthening economic security: [monograph] / VD Zalizko; National University of the State Tax Service of Ukraine. - Irpin: NUDPSU Publishing House, 2014. - 502 p.

11. Zalizko VD Rural territories of Ukraine: strategic priorities of development in the context of strengthening economic security: [monograph] / VD 
Економічні науки: збірник наукових праць Луцького національного технічного університету. Серія "Регіональна економіка". Випуск 18 (71). Редкол.: відп. ред. д.е.н., професор Л.Л. Ковальська. Луцьк: ІВВ Луцького НТУ, 2021. 278 с.

Zalizko; National University of the State Tax Service of Ukraine. - Irpin: NUDPSU Publishing House, 2014. - 502 p.

12. On Amendments to the Law of Ukraine "On Farming" to stimulate the establishment and operation of family farms: the law of Ukraine of 31.03.2016 № 1067-19 / Bulletin of the Verkhovna Rada (VVR), 2016, № 21, p.406

13. On Amendments to the Law of Ukraine "On Farming" to stimulate the establishment and operation of family farms: the law of Ukraine of 31.03.2016 № 1067-19 / Bulletin of the Verkhovna Rada (VVR), 2016, № 21, p.406

14. On amendments to the Law of Ukraine "On Farming" to stimulate the establishment and operation of family farms: the law of Ukraine of 31.03.2016 № 1067-19 / Bulletin of the Verkhovna Rada (VVR), 2016, № 21, p.406

15. On Amendments to the Law of Ukraine "On Farming" to stimulate the establishment and operation of family farms: the law of Ukraine of 31.03.2016 № 1067-19 / Bulletin of the Verkhovna Rada (VVR), 2016, № 21, p.406

16. Kaczynski AB Principles of system security analysis of complex systems. - Kyiv: SE "Euroatlantic Inform", 2006. - 336 p.

17. Blinov N., Kokarev M., Krasheninnikov V. On ensuring the economic security of Russia / N. Blinov, M. Kokarev, V. Krasheninnikov // Economist. - 1996. - № 4. - P. 47-51.

18. On Amendments to the Law of Ukraine "On Farming" to stimulate the establishment and operation of family farms: the law of Ukraine of 31.03.2016 № 1067-19 / Bulletin of the Verkhovna Rada (VVR), 2016, № 21, p.406

19. Talavyria M., Nikolenko L., Kolesnyk T., Samborska O. Ensuring the sustainable development of the Ukrainian agrarian sector in conditions of globalization. Problems and Perspectives in management. 2018. № 3. P. 245-258.

DOI: https://doi.org/10.36910/2707-6296-2021-18(71)-22 